\title{
The Influence of Learning Strategies and Learning Motivation against Islamic Fikih Students Learning Results in MIN 2 Labuhanbatu
}

\author{
Rusydi Ananda ${ }^{1}$, Heri Caniago ${ }^{2}$ \\ ${ }^{1,2}$ Faculty of Tarbiyah Science and Teacher Training, State Islamic University of North Sumatera, Medan, \\ Indonesia \\ rusdiananda.1972@gmail.com
}

\begin{abstract}
The purpose of this study was to determine and describe: (1) the effect of the application of learning strategies on the learning outcomes of Islamic Fikih, (2) the influence of learning motivation on the learning outcomes of Islamic Fikih, and (3) the interaction between strategies learning and learning motivation towards the learning outcomes of Islamic Fikih. The method used in this study is a quasi-experimental method. The study population was all students of class VI MIN 2 Labuhanbatu consisting of 3 classes. The sampling technique used was cluster random sampling, in which one group of classes was conducted using collaborative learning and the other class was conducted competitive learning. Data collection techniques used are lift and learning outcomes tests. The data analysis technique used is twoway analysis of variance. The research findings show: (1) there is an influence of learning strategies on fiqh learning outcomes. In this case the average learning outcomes of Islamic Fikih taught with collaborative learning strategies are higher than the average learning outcomes of Islamic Fikih taught with competitive learning strategies, (2) there is an influence of learning motivation on learning outcomes of Fikih. In this case, the average learning outcomes of Islamic Fikih with higher learning motivation is higher than the average learning outcomes of Fikih with low learning motivation, and (3) there is an interaction effect between learning strategies with learning motivation, where students with high learning motivation are more precisely taught using collaborative learning strategies, while students with low learning motivation are more precisely taught with competitive learning strategies.
\end{abstract}

Keywords

learning strategies, leaming motivation

\section{Introduction}

Substantially the subject of Fikih has a contribution in motivating students to practice and apply Islamic law in daily life as a manifestation of harmony, harmony, and balance of human relations with God Almighty, with the human self, fellow human beings, other creatures or the environment. Fikih in Islamic elementary schools aims to equip students to be able to: (1) know and understand ways of implementing Islamic law both concerning aspects of worship and muamalah to be used as guidelines for living in personal and social life, and (2) implementing and practicing provisions of Islamic law correctly and well, as an embodiment of obedience in carrying out the teachings of the Islamic religion both in human relations with God Almighty, with human beings themselves, fellow humans, and other creatures as well as relationships with their environment. 
Fikih is one of the fields of study given to students in madrasah ibtidayah, it needs to be given to students. Even though the actual lesson itself has actually been given since he was born by his parents. But formally it gets a madrasa. Studying religion is obligatory for every human being who understands. Learning starts from the crocodile to the grave. Although a person does not receive formal education but studying Fikih is an obligation that he must still do as a human being.

The selection of the right learning strategy is needed and must be adjusted to the motivation of students to learn, because studying Fikih material which is quite dense requires the independence of student learning in finding other sources. Therefore, the independence of student learning is one component that must be considered carefully by the teacher in identifying the abilities of students that will help in determining the right material, strategy, method and media to use. This needs to be done so that the learning delivered can attract the attention of students and every second that takes place in the learning activities carried out will be meaningful and not boring for students.

The learning strategies used by the teachers have not been optimal so as to cause student boredom resulting in low learning outcomes. To reduce or even avoid learning strategies that are too monotonous, various teaching strategies are pursued that are more effective in creating multi-directional communication, so that it is also expected to cause and increase proactive interactions in Fikih learning.

Collaborative learning strategies group learning where students learn through interaction with one another with fellow group members on the basis of a positive sense of interdependence, a sense of personal and group responsibility so that each student can maximize his potential both for his personal interests and for the interests of the group.

\section{Review of Literature}

Collaborative learning is small group learning where students jointly carry out tasks to maximize the results of their own learning and the learning outcomes of other group members. In this case collaborative learning is not limited to working together in a group but rather emphasizes a learning process that involves communication fully and fairly in the classroom (Jonassen, 1996).

There are five elements in collaborative learning. The five elements are explained by Gunawan (2004: 187) as follows: feeling of togetherness, mutual assistance, mutual respect, congratulations and celebrating mutual success, individual and group responsibilities in achieving learning success, intrapersonal and interpersonal communication, and reflection on functions and abilities they work together.

In line with the explanation above Davis (1993) explained the main characteristics of collaborative learning are: group cooperation to master teaching material, variations in membership in groups, groups have a measurable orientation. Furthermore, Hill and Hill (1996) explain two important elements in collaborative learning, namely shared goals and positive interdependence.

Johnson and Johnson (1997) suggest some basic elements of collaborative learning namely: (1) interdependence positive where group success is determined by the success of group members who interact positively, (2) there is direct interaction where group members meet directly in solving problems or completing tasks, (3) individual accountability and personal responsibility, where each individual plays their respective role which is vital for the success of the group as a whole. Therefore individual accountability or responsibility is emphasized, (4) collaborative skills, namely skills related to leadership, communication, decision making, trust formation, and conflict management, and (5) group processing in 
which groups are together - discuss how to work and interact effectively to achieve common goals.

Gunawan (2004) explains the steps of collaborative learning, namely: (1) initiation and apperception aimed at inviting and focusing students' attention, (2) formation of study groups, (3) completion of tasks in groups and (4) exposure or percentage Duty. Furthermore Gunawan (2004: 192) explains that there are three things that must be considered by teachers in implementing collaborative learning, namely: (1) grouping which is done by using the ability level reference must be done carefully. For this reason, try to be able to combine smart students with students who are rather slow with the intention that active learning takes place, (2) the number of group members must be cultivated a little. The ideal and most effective number if one group of three, 4 and a maximum of five people, and (3) collaborative learning is applied consistently and systematically, but should not be used excessively. The use of collaborative learning will be effective if the teacher understands the right time and situation.

Competitive learning strategies are learning strategies that emphasize the students' independent activities in learning. This type of learning is actually a type of learning that is commonly done in teachers so far. It is said to be competitive because of its emphasis on individualized reward systems. The learning setting is the class and students are given directions, explanations and assignments by the teacher then they do it individually without any direct interaction with their classmates.

Psychologically competitive learning takes place in the classroom is a reflection of the principle of individuality. Rohani and Ahmadi (2005) explain the principle of individuality in the context of learning as follows: each individual has different traits, talents and abilities, each individual has a way of learning in his own way, each individual has different special interests, each individual has a background (family) is different, each individual needs special guidance in accepting the lessons taught by the teacher according to individual differences and each individual has a different rhythm of growth and development.

Student activities in competitive learning are carried out by doing assignments according to their respective interests and abilities (Nasution, 2000). The purpose of competitive learning is to maximize the academic performance of each student in order to achieve the highest performance that may only be achieved by one or several students.

Schmuck \& Schmuck (2000) states that to achieve this goal students are encouraged to compete with the assumption that their classmates are rivals that must be defeated. Opportunities to compete individually can provide incentives and excitement for activities in class, whether the competition is to get prizes and praise or just for satisfaction. Regarding the implementation of competitive strategies, Johnson and Johnson (1997) state that the application of competitive strategies in schools is based on several assumptions that resemble myths: (1) our society currently lives in very competitive situations and students must be educated to compete so they can survive in a competitive situation, (2) achievement, extraordinary performance, the emergence of great leaders, encouragement, ambition, and motivation are very dependent on how far a person competes with others, (3) competition can build strong characters and strengthen life in the real world, (4) students prefer the atmosphere of competition, and (5) competition can increase self-confidence and self-esteem.

The syntax of collaborative learning is: (1) presentation of teaching material, (2) students are given assignments individually, (3) students complete assignments, (4) teachers and students examine the results of the assignment (Johnson and Johnson, 1997). For this reason, the following things need to be considered: (1) defining learning objectives explicitly, (2) students are given assistance and encouragement to achieve learning objectives, and (3) teachers give appreciation for student success. 
Competitive learning is rooted in the ideas of special cognitive psychology and theories of achievement motivation from McCelland. For this intellectual tradition, humans basically have the drive to pursue the highest achievements as a form of self-actualization. McCelland as quoted by Schmuck and Schmuck (2000) states that human motivation basically has three domains namely: (1) the drive for achievement shown by competence, ability, and curiosity, (2) the drive to power or have an influence on people others, and (3) encouragement for affiliation and affection.

Purwanto (2000) states that a motive is a conflicting statement in an organism that directs the behavior and actions of an organism that leads to a goal or incentive. The process of characterizing motives or activating motives is called motivation. A person's behavior is basically determined by his desire to achieve several goals. This desire will encourage someone to behave and this impulse is called motivation (Smittle, 2003).

Motivation is efforts to provide conditions so that individuals want or want to do it. In motivation as a dynamic force that drives someone to do something because in that motivation also stored various abilities to do something. Motivation as an inner factor (inner) functions to cause, underlie, direct one's actions. Likewise in work, motivation can arouse a person's impulse to really do activities that become his duties. Motivation can make someone persistent doing various activities. A teacher must be able to arouse motivation as an incentive that arouses students' passion for learning.

According to Davies (2001), states that the term motivation comes from Latin, namely movere which means to move. Based on these words, further definitions or understandings of motivation can be developed. The term motivation comes from the word motive which can be interpreted as the strength found in the individual, which causes the individual to act or act.

The learning process by choosing the right teaching method is very influential on the success of student learning. Thomas R. Hoer in Simorangkir (2019) states that different types of intelligence affect teaching and learning activities. Every intelligence has a different learning style. Therefore, the learning approach should be related to the environment and cultural context around the student's residence.

Hamalik (2004) explains that motivation has two components namely the inner component and the outer component. The inner component is a change in a person, a state of feeling dissatisfied, and psychological tension. The outer component is desire, and the purpose which directs one's actions. In other words, the inner component is the needs to be satisfied, while the outer component is the goal to be achieved.

Motivation encourages behavior and influences and changes behavior. Therefore Hamalik (2004) states that the motivational function is: (1) encouraging behavior or deeds. Without motivation there will be no action, for example learning, (2) motivation functions as a guide, meaning directing the action to achieve the desired goals, and (3) motivation functions as a mobilizer, meaning moving one's behavior. The size of the motivation will affect how quickly a job / task can be completed properly. Meanwhile Uno (2016) explained the motivation related to: (1) the hope of success in learning, (2) the spirit of achievement, and (3) having a high desire to learn.

Uno in Pohan (2020) states that "learning motivation is internal and external encouragement to students who are learning to make changes in behavior". Likewise in mathematical lessons in order to achieve maximum results there must be motivation to learn. When students' motivation to learn is high, teaching and learning activities tend to increase in the sense that learning will be active and students who learn will truly follow the teaching and learning process so that the expected learning objectives can be achieved.

Motivation and learning are two things that cannot be separated and influence each other. Learning is a change in behavior that is relatively permanent and potentially occurs as 
a result of practice or reinforcement based on the goal to achieve certain goals. Motive can be said as a driving force to do certain activities in order to achieve a goal. Sardiman (2011:71) says that motivation is a change in energy in a person that is characterized by the appearance of "feeling" and preceded by a response to the existence of goals. (Lumbantobing, 2020)

Based on the explanation above it can be concluded that learning motivation is an impetus (energy) or a factor that can influence, cause, direct, and organize human behavior in meeting the desired learning objectives. Learning motivation greatly influences students in increasing their willingness and enthusiasm to learn in achieving a goal. Furthermore, it can be stated that the indicators of learning motivation are: (1) expectations for success in learning, (2) desire to learn, (3) encouragement to succeed, and (4) enthusiasm for achievement.

\section{Research Methods}

The method used in this study is a quasi-experimental method. The study population was all students of class VI Madrasah Ibtidaiyah Negeri 2 Labuhanbatu consisting of 3 classes. The sampling technique used was cluster random sampling, in which one group of classes was conducted using collaborative learning and the other class was conducted competitive learning. Data collection techniques used are lift and learning outcomes tests. The data analysis technique used is two-way analysis of variance.

\section{Discussion}

The average learning outcomes of Fikih students taught with collaborative learning strategies $(=28,15)$ are higher than the average Fikih students taught with competitive learning strategies $(=26.92)$. This shows that the collaborative learning strategy is proven to be effective in improving the learning outcomes of Fikih students as a whole both for groups of students with high learning motivation and low learning motivation. From these findings it is shown that to teach Fikih material is more effective using collaborative learning strategies than with competitive learning strategies.

The average learning outcomes of Fikih students with high motivation $(=32.36)$ are better than the learning outcomes of Islamic Fikih Ibtidaiyah Islamic State 2 students with low motivation $(=25,84)$. While in competitive learning strategies, the average learning outcomes of Islamic Fikih 2 Labuhanbatu Madrasah students with high learning motivation ( $=28.11)$ is better than the results of Fikih of Islamic Ibtidaiyah Madrasah 2 students in Labuhanbatu with low learning motivation $(=26.04)$.

The first hypothesis which states the results of Fikih among students of Madrasah Ibtidaiyah Negeri 2 Labuhanbatu taught with collaborative learning strategies is higher than the results of Fikih of students taught with competitive learning strategies, this is evidenced based on factorial $2 \times 2$ calculation obtained Fcount $=29.57$ while the value of Ftable $=3.96$ for $\mathrm{dk}(1.76)$ and the real level $\alpha=0.05$. it turns out that the value of Fcount $=29.57>$ Ftable $=3.96$

Collaborative learning strategies aim at fostering student participation in solving issues or problems raised by teachers in learning, fostering discussions among students as explained by Poejiadi (2004: 89) that collaborative learning is based on constructivism learning theory, which in principle illustrates that students form or build his knowledge through his interactions with his environment.

Therefore the teacher's role in collaborative learning as a facilitator leads students to find and construct their own knowledge. This is in line with the phrase Sudjana (2002) 
explains the greater the effort to create the conditions of the teaching process, the higher the results or products of the teaching. The findings of this study support the findings of previous studies including: Tint and Nyunt (2015) research by Dewi, Mudakir, Murdiyah (2016) Ni'matuzahroh research (2015) and Lasidos Research, Zulkifli Matondang (2015).

The second hypothesis testing shows that the learning outcomes of Fikih of Islamic Elementary School 2 Labuhanbatu Madrasah students with high learning motivation is higher than the results of Fikih of Islamic Elementary School 2 Madrasah Ibtidaiyah students with low learning motivation. This refers to the calculation of factorial anova $2 \times 2$ obtained Fcount $=4.43$ while the value of Ftable $=3.96$ for $\mathrm{dk}(1.76)$ and the real level $\alpha=0.05$. It turned out that the value of Fcount $=4.43>$ Ftable $=3.96$.

This finding proves that learning motivation is significant for distinguishing fiqh learning outcomes. Learning motivation in this study is categorized into two categories, namely high learning motivation and low learning motivation. This shows that learning motivation is significant enough to differentiate student learning outcomes, where student learning outcomes with high learning motivation both those taught with collaborative learning strategies and competitive learning strategies are better than student learning outcomes with low learning motivation.

The role of motivation with the success of Madrasah Ibtidaiyah Negeri 2 Labuhanbatu students in learning is very close and inseparable. The higher the motivation to learn a student, the greater the effort he does to achieve successful learning. Because motivation in a person becomes a mover (motor) that will activate all the existing energy, including learning activities. Thus, it can be stated that learning motivation has a positive and significant relationship with student learning outcomes.

The results of the overall data analysis obtained by the average learning outcomes of Islamic Fikih students in Islamic State 2 Labuhanbatu with high learning motivation is better than the results of Fikih students with low learning motivation. This indicates that students with high learning motivation on average have better fiqh learning outcomes compared to students with low learning motivation. Thus students with high learning motivation understand and master the subject matter of Fikih compared to students with low learning motivation.

This is in line with the explanation of Hamalik (2004) which states that the motivational function is: (1) encouraging behavior or deeds. Without motivation there will be no action, for example learning, (2) motivation functions as a guide, meaning directing the action to achieve the desired goals, and (3) motivation functions as a mobilizer, meaning moving one's behavior. The size of the motivation will affect how quickly a job / task can be completed properly. The findings of this study support previous research including: Mappease research (2009), Suprihatin research (2015) and Nurdin research (2015).

The third hypothesis testing there is an interaction between learning strategies and learning motivation in influencing the learning outcomes of Islamic Fikih 2 Labuhanbatu Madrasah students. When seen the average learning outcomes of Fikih in groups of students with high learning motivation taught with collaborative learning strategies higher than the average learning outcomes of Fikih groups of students with low learning motivation and taught with competitive learning strategies.

The average learning outcomes of Fikih in the group of Madrasah Ibtidaiyah Negeri 2 Labuhanbatu students with low learning motivation taught with collaborative learning strategies are lower than the average learning outcomes of Fikih in the group of Madrasah Ibtidaiyah Negeri 2 Labuhanbatu students with low learning motivation taught with learning strategies competitive. 
This means that for groups of students with high learning motivation it is better to use collaborative learning strategies while students with low learning motivation are better taught by using competitive learning strategies. Thus it can be concluded that the learning strategy and learning motivation significantly influence the learning outcomes of Islamic Fikih 2 Labuhanbatu Madrasah students.

This is possible because through collaborative learning: (1) students practice integrating concepts obtained from instructors' explanations or from books / readings with their application in daily life, (2) students are given the opportunity to look for information outside the classroom both information that is nature objects / readings, visions (competitive objects, TV / radio / internet) or people / experts or figures, (3) students make alternatives to overcome the topics / objects discussed, (4), students make decisions (according to their abilities) that related to the concepts that have been learned by considering the values that exist in society, (5) formulating steps that will be taken to overcome the problem and prevent the emergence of problems related to the topics discussed.

Scheffe test results show that from six combinations of average comparison of Islamic Fikih 2 Labuhanbatu Madrasah students' learning outcomes there are three of six showing insignificant results, namely: (1) collaborative learning strategies and high learning motivation with Madrasah Ibtidaiyah 2 Madrasah students taught with competitive learning strategies and high learning motivation, (2) collaborative learning strategies and high learning motivation with collaborative learning strategies with learning motivation, and (3) collaborative learning strategies and high learning motivation with competitive learning strategies and low learning motivation.

\section{Conclusion}

The conclusions of the research findings are as follows: (1) there is an influence of learning strategies on the learning outcomes of Fikih. In this case the average learning outcomes of Fikih taught with collaborative learning strategies are higher than the average learning outcomes of Fikih taught with competitive learning strategies, (2) there is an influence of learning motivation on learning outcomes of Fikih. In this case the average learning outcomes of figh students with high learning motivation is higher than the average learning outcomes of fiqh students with low learning motivation, and (3) there is an influence of interaction between learning strategies with learning motivation, where students with learning motivation Higher learning is more precisely taught using collaborative learning strategies, while students with low learning motivation are more precisely taught by competitive learning strategies.

Suggestions that can be delivered in connection with the findings of this study are: (1) Teachers as learning designers are advised to pay attention to the characteristics of students in threatening learning so that teachers can determine the choice of learning strategies that are more appropriate to be implemented because learning strategies and student characteristics are a component that can be determine and influence learning outcomes, (2) teachers in learning activities need to implement collaborative learning strategies in fiqh learning, because collaborative learning strategies provide higher learning outcomes in fiqh subjects compared to competitive learning strategies. 


\section{References}

Ananda, Rusydi and Fadhli, Muhammad. (2018). Statistik Pendidikan. Teori Dan Praktek Dalam Pendidikan. Medan; Widya Puspita.

Davis, A.(1993) Colaborative Learning. http://www. wcer.wisc.edu/archie/ cli/cl/ doingclk/DCL1.asp.

Davies, Ivor K. (2001). The Management of Learning. Diterjemahkan ke dalam Bahasa Indonesia oleh Sudarsono Sudirjo dkk. Cetakan Kedua. Jakarta: Rajawali bekerjasama Dengan Pusat Antar Universitas di Universitas Terbuka.

Dewi, dkk. (2016) .Pengaruh Model Pembelajaran Kolaboratif berbasis Lesson Study Terhadap Kemampuan Berpikir Kritis Siswa, Jurnal: Edukasi UNEJ, III (2): 29-33

Gunawan, Adi. W. Genius. (2004) .Learning Strategi. Jakarta: Grasindo.

Hamalik, Oemar. (2004). Proses Belajar Mengajar. Jakarta: Bumi Aksara.

Hill, S. and Hill, T. (1996) The Collaborative Classroom, A Guide to Cooperative Learning. Armadale Vic: Eleanor Curtain Publishing.

Johnson, D. W. and Johnson, F.P. (1997).Joining Together, Group Theory and Group Skills. Boston: Allyn and Bacon.

Jonnasen, D.H. (1996).Handbook of Research for Educational Communications and Technology. New York: MacMillan Library Reference USA.

Lasidos, Pahala Arion dan Matondang, Zulkifli. Penerapan Model Pembelajaran Kolaboratif Untuk Meningkatkan Aktivitas Dan Hasil Belajar Rencana Anggaran Biaya Siswa Kelas Xii Kompetensi Keahlian Teknik Gambar Bangunan Smkn 2 Siatas Barita Tapanuli Utara. Jurnal Educational Building Volume 1, Nomor 1, Juni 2015 : 13 - 22, ISSN : 2477-4898

Lumbantobing, P. (2020). The Contribution of Lecturer Pedagogical Competence, Intellectual Intelligence and Self-Efficacy of Student Learning Motivation, Budapest International Research in Linguistics and Education Sciences (BirLE), P.564-573.

Nasution, S. (2000). Dikdaktik Asas-Asas Mengajar. Jakarta: Bumi Aksara.

Ni'matuzahroh.(2015).Efektifitas Strategi Membaca Kolaboratif Untuk Meningkatan Pemahaman Bacaan Siswa Sekolah Dasar, Jurnal RAP UNP, Vol. 6, No. 2, November.

Pohan, A. (2020). The Effect of Problem Based Learning and Learning Motivation of Mathematical Problem Solving Skills of Class 5 Students at SDN 0407 Mondang, Budapest International Research in Linguistics and Education Sciences (BirLE), P. 531-539.

Purwanto, M. Ngalim. (2006). Psikologi Pendidikan. cetakan kelima. Bandung: Remaja Rosdakarya.

Rohani, Ahmad and Ahmadi, Abu. (2005).Pengelolaan Pengajaran. Jakarta: Rineka Cipta.

Schmuck, R.A. and Schmuck, P.A. (1980).Group Processes in the Classroom. Dubuque, Iowa: WM. C. Brown.

Simorangkir, F. (2019). Implementation of Multiple Intelligences Approach Based On Batak Angkola Culture in Learning Thematic For Class IV SD Negeri 100620 Pargarutan Julu South Tapanuli District. Budapest International Research in Linguistics and Education Sciences (BirLE), P.547-551.

Smittle, Patricia. (2003).Principles for Effective Teaching. Journal of Developmental Education, Volume 26, Issue 3, http://www.nede.appstate.edu/resources/ reports/documents. 